\title{
Effects of ammonium application rate on uptake of soil adsorbed amino acids by rice
}

\author{
Xiao-chuang $\mathrm{CAO}^{\S \dagger 1}$, Qing-xu $\mathrm{MA}^{\S 2}$, Liang-huan $\mathrm{WU}^{\dagger \ddagger 2}$, Lian-feng ZHU ${ }^{1}$, Qian-yu $\mathrm{JIN}^{1}$

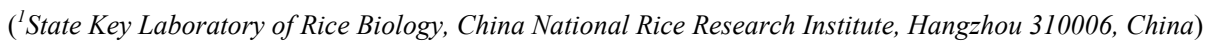 \\ $\left({ }^{2}\right.$ Ministry of Education Key Laboratory of Environmental Remediation and Ecosystem Health, \\ College of Environmental and Resource Sciences, Zhejiang University, Hangzhou 310058, China) \\ †E-mail: caoxiaochuang@126.com; finm@zju.edu.cn \\ Received Aug. 28, 2015; Revision accepted Dec. 8, 2015; Crosschecked Mar. 18, 2016
}

\begin{abstract}
In recent years, excessive use of chemical nitrogen $(\mathrm{N})$ fertilizers has resulted in the accumulation of excess ammonium $\left(\mathrm{NH}_{4}{ }^{+}\right)$in many agricultural soils. Though rice is known as an $\mathrm{NH}_{4}{ }^{+}$-tolerant species and can directly absorb soil intact amino acids, we still know considerably less about the role of high exogenous $\mathrm{NH}_{4}{ }^{+}$content on rice uptake of soil amino acids. This experiment examined the effects of the exogenous $\mathrm{NH}_{4}{ }^{+}$concentration on rice uptake of soil adsorbed glycine in two different soils under sterile culture. Our data showed that the sorption capacity of glycine was closely related to soils' physical and chemical properties, such as organic matter and cation exchange capacity. Rice biomass was significantly inhibited by the exogenous $\mathrm{NH}_{4}{ }^{+}$content at different glycine adsorption concentrations. A three-way analysis of variance demonstrated that rice glycine uptake and glycine nutritional contribution were not related to its sorption capacity, but significantly related to its glycine: $\mathrm{NH}_{4}{ }^{+}$concentration ratio. After $21-\mathrm{d}$ sterile cultivation, the rice uptake of adsorbed glycine accounted for $8.8 \%-22.6 \%$ of rice total $\mathrm{N}$ uptake, which indicates that soil adsorbed amino acids theoretically can serve as an important $\mathrm{N}$ source for plant growth in spite of a high $\mathrm{NH}_{4}{ }^{+}$application rate. However, further studies are needed to investigate the extent to which this bioavailability is realized in the field using the ${ }^{13} \mathrm{C},{ }^{15} \mathrm{~N}$ double labeling technology.
\end{abstract}

Key words: Soil adsorbed glycine, Ammonium, Glycine uptake, Glycine bioavailability, Sterile cultivation http://dx.doi.org/10.1631/jzus.B1500203

CLC number: S158.5

\section{Introduction}

Traditionally, the terrestrial nitrogen $(\mathrm{N})$ cycle asserts that soil organic $\mathrm{N}$ must be transformed into inorganic $\mathrm{N}\left(\mathrm{NO}_{3}{ }^{-}\right.$and $\left.\mathrm{NH}_{4}{ }^{+}\right)$by soil microorganisms prior to becoming available to plant roots (Warren and Adams, 2007). However, the role of soil dissolved organic $\mathrm{N}(\mathrm{DON})$, such as amino acids, in meeting the

\footnotetext{
ॠ Corresponding author

$\S$ The two authors contributed equally to this work

* Project supported by the Zhejiang Provincial Natural Science Foundation of China (No. LQ15C130004), the National Basic Research Program (973) of China (No. 2015CB150502), and the National Natural Science Foundation of China (Nos. 31172032 and 31270035) (1D) ORCID: Xiao-chuang CAO, http://orcid.org/0000-0002-3630-1556

(c) Zhejiang University and Springer-Verlag Berlin Heidelberg 2016
}

plant nutritional requirement has since the 1990s received much attention (Jones et al., 2005a; Näsholm et al., 2009; Vinall et al., 2012; Wang et al., 2013; Geisseler and Horwath, 2014). Numerous studies have shown that both mycorrhizal and non-mycorrhizal plants can directly absorb soil amino acids, thereby circumventing the traditional mineralization bottleneck (Näsholm et al., 2001; Persson and Näsholm, 2001; Warren, 2006; Rothstein, 2009; Wang et al., 2014). Especially in some low $\mathrm{N}$-input and cold ecosystems, plant uptake of amino acid has the potential to be a primary factor in ecosystem functioning and vegetation succession (Raab et al., 1999; Henry and Jefferies, 2003; Warren, 2006; Månsson et al., 2014). 
To quantitatively analyze the role of amino acids in plant $\mathrm{N}$ uptake, comparisons were always made between the pool of soil extractable organic and inorganic $\mathrm{N}$ in different ecosystems. Soil $\mathrm{N}$ is dominated by organic forms, of which $30 \%-45 \%$ is present as amino acids after the process of proteolysis (Stevenson, 1994). Many studies have shown that the contents of free amino acids in soil solution are typically less than $1 \%$ of the pool of DON at about $0.1-50.0 \mu \mathrm{mol} / \mathrm{L}$ in different ecosystems (Jones et al., 2002; Yu et al., 2002; Christou et al., 2006). However, most studies neglected the fact that amino acid can be readily adsorbed on the soil solid phase, and its content may account for as much as $88 \%-92 \%$ of total soil amino acids (Qualls and Richardson, 2003). It has been reported that soil adsorption capacity is closely related to amino acid concentration (Jones et al., 2013), soil clay content (Gonod et al., 2006), cation exchange capacity (Dashman and Stotzky, 1984), and so on. Therefore, further research on soil organic $\mathrm{N}$ composition should include the consideration of soil adsorbed amino acids in different ecosystems.

$\mathrm{NH}_{4}{ }^{+}$, one of the two important inorganic $\mathrm{N}$ sources used by plants, is beneficial for plant growth under many circumstances, and indeed, serves as a ubiquitous intermediate in plant metabolism (Britto and Kronzucker, 2002). A survey of boreal and temperate forest ecosystems shows forest-floor soil solution $\mathrm{NH}_{4}{ }^{+}$values ranging from approximately 0.4 to $4.0 \mathrm{mmol} / \mathrm{L}$, with a mean value of $2.0 \mathrm{mmol} / \mathrm{L}$ (Bijlsma et al., 2000). In agricultural soils, $\mathrm{NH}_{4}{ }^{+}$can be even higher, often ranging from 2 to $20 \mathrm{mmol} / \mathrm{L}$ (Britto and Kronzucker, 2002). Especially in recent years, the excessive use of $\mathrm{N}$ fertilizer leads to $\mathrm{N}$ volatilization and subsequent transport and deposition of $\mathrm{NH}_{3} / \mathrm{NH}_{4}{ }^{+}$via the atmosphere, resulting in undesirable accumulation of $\mathrm{NH}_{4}{ }^{+}$and acidification in agricultural soils (Guo et al., 2010; Li et al., 2011b; Liu et al., 2013). Previous studies have explored several important physiological links in the development of high $\mathrm{NH}_{4}{ }^{+}$accumulation or $\mathrm{NH}_{4}{ }^{+}$toxicity, such as rhizosphere acidification, nutrient imbalance, damage to the photosynthesis system, and carbohydrate limitation (Britto and Kronzucker, 2002; Qin et al., 2008; Balkos et al., 2010; Barth et al., 2010; Li et al., 2010; Kempinski et al., 2011). Britto et al. (2001) demonstrated that rice could maintain lower symplastic concentrations of $\mathrm{NH}_{4}{ }^{+}$than barley (known to be susceptible to $\mathrm{NH}_{4}{ }^{+}$toxicity) under elevated $\mathrm{NH}_{4}{ }^{+}$concentration, in part because it is capable of shifting the trans-plasmamembrane electrical potential $(\Delta \psi)$ to more positive values with increasing $\mathrm{NH}_{4}{ }^{+}$concentration. Though rice is known as an $\mathrm{NH}_{4}{ }^{+}$-tolerant species, we still know considerably less about the effects of the different exogenous $\mathrm{NH}_{4}{ }^{+}$ application rates on rice amino acid uptake.

Here, two different soils, differing in soil parent material, texture, land use history and elevation, were selected from the alpine and agro-ecosystems. According to Fick's second diffusion law, a higher adsorbed capacity between root surface and its surrounding soil would lead to an accelerated compensation of concentration differences, and facilitate the transport of tracer to the root surface (Sauheitl et al., 2009). So increasing adsorbed glycine concentration will increase the transport of glycine to the root surface and thus increase the uptake of glycine. Therefore, our aims were to: (1) analyze the difference of the adsorption capacity of amino acids and the influencing factors in the two different soils, and (2) investigate whether plant uptake of soil adsorbed amino acids and its nutritional contribution are positively related to its sorption capacity under the condition of excessive $\mathrm{NH}_{4}{ }^{+}$application.

\section{Materials and methods}

\subsection{Soil sampling}

The selected two different soils, soil A and soil B, were sampled from the agricultural and alpine ecosystems, respectively. Soil A is a silt loam from Xiaoshan, a suburb of Hangzhou, China ( $30^{\circ} 3^{\prime} 59.2^{\prime \prime} \mathrm{N}$, $120^{\circ} 15^{\prime} 31.4^{\prime \prime} \mathrm{E}$, altitude of $10 \mathrm{~m}$ ), and has a long history of rice production. Soil B is a clay loam and was collected from the town of Guangdu, Taizhou, China $\left(28^{\circ} 56^{\prime} 39.6^{\prime \prime} \mathrm{N}, 120^{\circ} 46^{\prime} 39.6^{\prime \prime} \mathrm{E}\right.$, altitude of $700 \mathrm{~m}$ ). Full details of the two sites may be found in Cao et al. (2013). The soil samples were taken on Apr. 15-20, 2011. All the fresh soils were air-dried and stored under ventilated conditions. Then the soils were sieved to pass $2 \mathrm{~mm}$ and all observable roots were removed. Selected properties of the two soils are shown in Table 1 (Cao et al., 2013). 
Table 1 Chemical and physical properties of the two soils ${ }^{*}$

\begin{tabular}{lcc}
\hline \multicolumn{1}{c}{ Properties } & Soil A & Soil B \\
\hline Texture & Silt loam & Clay loam \\
Water content $(\mathrm{g} / 100 \mathrm{~g})$ & 45 & 34 \\
$\mathrm{pH}\left(\mathrm{H}_{2} \mathrm{O}\right)$ & 6.43 & 5.09 \\
Organic $\mathrm{C}(\mathrm{g} / 100 \mathrm{~g})$ & 6.84 & 3.15 \\
$\mathrm{~N}_{\text {tot }}(\mathrm{g} / 100 \mathrm{~g})$ & 0.37 & 0.16 \\
$\mathrm{C}: \mathrm{N} \mathrm{ratio}$ & 18.5 & 19.7 \\
$\mathrm{P}_{\text {tot }}(\mathrm{g} / 100 \mathrm{~g})$ & 0.014 & 0.472 \\
$\mathrm{~K}_{\text {tot }}(\mathrm{g} / 100 \mathrm{~g})$ & 0.14 & 0.22 \\
$\mathrm{CaCO}(\mathrm{g} / 100 \mathrm{~g})$ & 11.4 & 10.4 \\
Total soluble salt $(\mathrm{g} / 100 \mathrm{~g})$ & 2.3 & 0.5 \\
Exchangeable cation & & \\
$\mathrm{Ca}(\mathrm{cmol} / \mathrm{kg})$ & 7.5 & 4.1 \\
$\mathrm{Mg}(\mathrm{cmol} / \mathrm{kg})$ & 0.62 & 0.44 \\
$\mathrm{~K}(\mathrm{cmol} / \mathrm{kg})$ & 0.37 & 0.28 \\
$\mathrm{Na}(\mathrm{cmol} / \mathrm{kg})$ & 0.04 & 0.02 \\
$\mathrm{Fe}(\mathrm{mg} / \mathrm{kg})$ & 101.9 & 87.3 \\
$\mathrm{Zn}(\mathrm{mg} / \mathrm{kg})$ & 3.7 & 1.7 \\
Available S $(\mathrm{mg} / \mathrm{kg})$ & 26.2 & 8.4 \\
Available P $(\mathrm{mg} / \mathrm{kg})$ & 8.6 & 53.2 \\
\hline
\end{tabular}

* Reprinted from Cao et al. (2013), Copyright 2013, with permission from Elsevier. $\mathrm{N}_{\text {tot }}$ t total $\mathrm{N} ; \mathrm{P}_{\text {tot }}$ : total $\mathrm{P} ; \mathrm{K}_{\text {tot }}$ t total $\mathrm{K}$

\subsection{Amino acid sorption}

We performed soil washing, soil sterilization, and glycine adsorption as the method described in our previous studies (Cao et al., 2013; Chen et al., 2013). Once air-dried, 57 15-g sub-samples for soil A and 57 20-g sub-samples for soil B were successively washed five times with $0.5 \mathrm{~mol} / \mathrm{L} \mathrm{K}_{2} \mathrm{SO}_{4}$ at a soil:solution ratio of 1:5 (w:v), shaken (150g, $60 \mathrm{~min})$, centrifuged $(4000 \mathrm{~g}, 10 \mathrm{~min})$, and then filtered through Whatman No. 42 filter paper. Then soils were washed with sterilized water as described above to leach the potassium $(\mathrm{K})$ ion that was in the soils. Finally, each of 57 samples was thoroughly mixed and put in a hyperthermia disinfection pot (YXQ-LS-50G, China) for sterilization at $121{ }^{\circ} \mathrm{C}$ for $1 \mathrm{~h}$. The process of soil mixture and sterilization was repeated three times. The inoculation of the sterilized soil to agar plates did not indicate any microbial growth for at least $30 \mathrm{~d}$, proving that the soil sterilization process was effective.

Among the above-mentioned sterilized soils, 39 repetitions for each of soil A and soil B were used for studying glycine sorption capacity, and $75 \mathrm{ml}$ unlabeled glycine solution for soil A and $100 \mathrm{ml}$ unlabeled glycine solution for soil B with concentrations of 0,5 , $10,15,30,60,120,240,480,700,800,1000$, and $1200 \mathrm{mg} / \mathrm{L}$ were added to each repetition. Each concentration had three replications. In addition, $10 \mathrm{mg} / \mathrm{L}$ ampicillin was added to the glycine solution in order to inhibit the growth of microbes. Then the soil and solution mixtures were shaken $(150 \mathrm{~g}, 60 \mathrm{~min})$, centrifuged $(4000 \mathrm{~g}, 10 \mathrm{~min})$, and filtrated through a $0.22-\mu \mathrm{m}$ millipore filter (Millipore, PES Membrane, Ireland). The glycine sorption capacity was calculated based on the glycine concentration differences between the added solution and the filtrate. In addition, desorption experiments with the sterilized water proved that $88 \%-92 \%$ of the added glycines were adsorbed on the soil solid phase (data not shown). Then the quantified glycine adsorption saturated (AS) and half adsorption saturated (HAS) concentrations were selected for the glycine uptake experiment described in the next section.

\subsection{Experimental set-up}

The remaining sterilized soils, 18 repetitions for each of soil A and soil B, were used to investigate the effects of the adsorbed glycine on rice growth, glycine uptake, and glycine nutritional contribution. According to the glycine sorption curve, the ${ }^{15} \mathrm{~N}$-glycine (atom percentage excess 50.18\%) HAS solution at the soil:solution ratio of 1:5 (w:v) was added to each 9 repetitions of soil A and soil B. While the ${ }^{15} \mathrm{~N}$-glycine AS solution at the soil:solution ratio of 1:5 (w:v) was added to the remaining 9 repetitions. The mixture of soil and ${ }^{15} \mathrm{~N}$-glycine solution was mixed thoroughly, shaken $(150 \mathrm{~g}, 60 \mathrm{~min})$, centrifuged $(4000 \mathrm{~g}, 10 \mathrm{~min})$, and filtered through Whatman No. 42 filter paper. The soils of ${ }^{15} \mathrm{~N}$-glycine HAS and AS solutions were transferred to $15 \mathrm{ml}$ centrifugal tubes for rice cultivation. In order to keep the rice seedlings' growth healthy and to fill the tubes to approximately the same depth, $15 \mathrm{~g}$ of soil A and $20 \mathrm{~g}$ of soil B were required in each tube.

Six treatments were set for each of soil A and soil $\mathrm{B}$. The weight ratios of the added ${ }^{15} \mathrm{~N}$-glycine and $\mathrm{NH}_{4}{ }^{+}-\mathrm{N}$ in different treatments were as follows: (1) adsorbed glycine: $\mathrm{NH}_{4}{ }^{+}$weight content is 1:2 (T1), 1:1 (T2), 1:0.5 (T3) at glycine HAS concentration; (2) adsorbed glycine: $\mathrm{NH}_{4}{ }^{+}$weight content is 1:2 (T4), 1:1 (T5), 1:0.5 (T6) at glycine AS concentration. The unlabeled $\mathrm{NH}_{4}{ }^{+}$was injected into the soil using a $0.25-\mathrm{ml}$ capacity Eppendorf pipette four times. Besides the $\mathrm{N}$ element, each tube was also replenished with $2 \mathrm{ml}$ macro-element solution containing $0.025 \mathrm{mmol} / \mathrm{L}$ $\mathrm{KH}_{2} \mathrm{PO}_{4}, 0.025 \mathrm{mmol} / \mathrm{L} \quad \mathrm{K}_{2} \mathrm{HPO}_{4}, 0.125 \mathrm{mmol} / \mathrm{L}$ $\mathrm{K}_{2} \mathrm{SO}_{4}, 0.100 \mathrm{mmol} / \mathrm{L} \mathrm{MgSO}_{4}$, and $0.200 \mathrm{mmol} / \mathrm{L}$ $\mathrm{CaCl}_{2}$. Each treatment was repeated three times. 
The sterilized rice seedlings were obtained as follows: (1) rice seeds were first immersed in 70\% ethanol for $1 \mathrm{~min}$ and then rinsed three times with sterile distilled water, (2) secondly immersed in $0.02 \mathrm{~g} / \mathrm{ml}$ sodium hypochlorite solution for $5 \mathrm{~min}$ and then rinsed five times with sterile distilled water, and (3) finally immersed in $1.0 \mathrm{~g} / \mathrm{L}$ mercuric chloride for $5 \mathrm{~min}$ and then rinsed with sterile distilled water six times. The sterile seeds were then allowed to germinate on a double layer of moistened paper at $25^{\circ} \mathrm{C}$ in the dark. When the main root was approximately $1.0 \mathrm{~cm}$ long after $7 \mathrm{~d}$ of germination, two germinated seedlings were transplanted into the cultivation tube. The sterile seedlings were also cultivated as the previous method (Cao et al., 2013). Briefly, the sterile seedlings were placed in a plant organic nutritional laboratory at $30{ }^{\circ} \mathrm{C} / 25{ }^{\circ} \mathrm{C}$ (day/night) with a relative humidity of $60 \%$, a maximum photosynthetic photon flux density of $300 \mu \mathrm{mol} /\left(\mathrm{m}^{2} \cdot \mathrm{s}\right)$, and a 12 -h photoperiod. Rice seedlings were watered with sterile water as needed during the period of cultivation.

\subsection{Calculations and statistics}

After 21-d sterile cultivation, rice seedlings were randomly destructively harvested. Any soil adhering to the root was removed by gentle agitation in $0.5 \mathrm{mmol} / \mathrm{L} \mathrm{CaCl}_{2}$ solution for $30 \mathrm{~min}$, and thoroughly washed with distilled water to remove traces adsorbed on the root surface. Then whole plant samples were dried to a constant weight in an oven at $60{ }^{\circ} \mathrm{C}$ for $48 \mathrm{~h}$. The dried samples were weighed and ground to a fine powder using a ball mill (MM2, Retsch, Dusseldorf, Germany). Plant N content was determined by the micro-Kjeldahl method and titrated with $0.05 \mathrm{mmol} / \mathrm{L} \mathrm{H}_{2} \mathrm{SO}_{4}$. The ${ }^{15} \mathrm{~N}$ enrichment of plant materials was determined using a Tracer MAT-271 (Finnigan MAT, USA). Excess ${ }^{15} \mathrm{~N}$ (atom percentage excess) was calculated as the difference between ${ }^{15} \mathrm{~N}$ in the plant samples from the soil adsorbed ${ }^{15} \mathrm{~N}$ glycine and ${ }^{15} \mathrm{~N}$ in the treatment with unlabeled $\mathrm{N}$ forms (Warren and Adams, 2002). ${ }^{15} \mathrm{~N}$ values and rice $\mathrm{N}$ concentration were then used to calculate rice glycine uptake and its nutritional contribution to rice total $\mathrm{N}$ uptake, according to the method described by Cao et al. (2013).

All the data are presented as the mean \pm standard error (SE). Differences in plant biomass, glycine uptake, and glycine nutritional contribution for each soil type were analyzed by one-way analysis of variance (ANOVA). The differences in mean values were tested using Duncan's multiple range method $(P<0.05)$. Three-way ANOVA was used to test the effects of soil type, adsorbed glycine content, glycine: $\mathrm{NH}_{4}{ }^{+}$concentration ratio, and their interaction on rice biomass, glycine uptake, and glycine nutritional contribution. Statistical analyses were performed by Statistica v.5.5 (StatSoft Inc., USA).

\section{Results}

\subsection{Glycine sorption capacity}

As shown in the study of Cao et al. (2013), generally the amount of amino acid adsorbed was concentration-dependent, and soil A had a higher sorption capacity than soil B (Fig. 1). At low glycine concentrations, there was no significant difference of adsorption rates between the two soils. However, the adsorbed rate of soil A exhibited a more rapid increase with increasing glycine concentrations, and reached an equilibrium at a much higher glycine concentration than that of soil B. Glycine sorption appeared to be close to saturation at approximately 700 and $480 \mathrm{mg} / \mathrm{L}$ for soil A and soil B, respectively. Their total sorption capacities calculated were 1490 and $280 \mathrm{mg} / \mathrm{kg}$ for soil A and soil B, respectively.

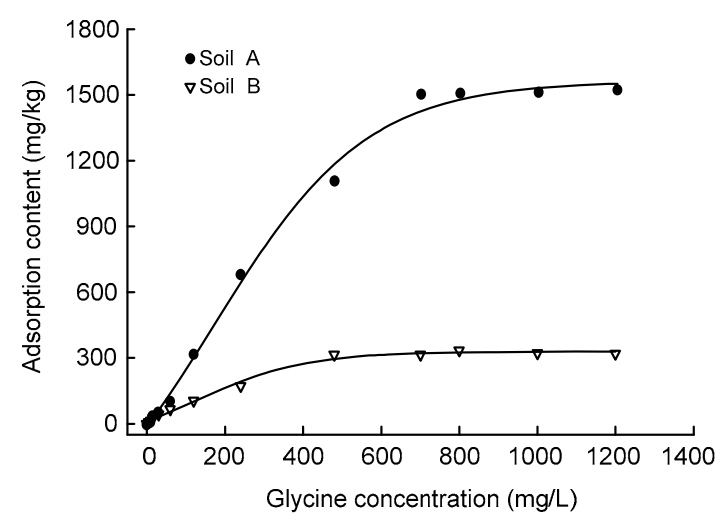

Fig. 1 Adsorption isotherm of the adsorbed glycine on soil that had been successively washed five times with $0.5 \mathrm{~mol} / \mathrm{L} \mathrm{K}_{2} \mathrm{SO}_{4}$

Values represent means of three replications. Reprinted from Cao et al. (2013), Copyright 2013, with permission from Elsevier

\subsection{Rice biomass}

As shown in Fig. 2, the high $\mathrm{NH}_{4}{ }^{+}$application rate significantly inhibited rice growth relative to the 
low $\mathrm{NH}_{4}^{+}$treatment in both soils except T5 in soil B $(P<0.05$; Fig. 2a). Rice biomass (shoot plus root) reached the highest in T3 treatment with the lowest $\mathrm{NH}_{4}^{+}$content, i.e. about 155.0 and $115.7 \mathrm{mg} /$ plant for soil A and soil B, respectively. There were no significant differences between the three AS and three HAS treatments, which had been supplied with an equal $\mathrm{NH}_{4}{ }^{+}$content in soil $\mathrm{A}$, but the variation was not significant in soil B. Under the treatment of equal $\mathrm{N}$ concentration, rice biomass in T6 relative to T1 increased by $119.3 \%$ and $23.3 \%$ for soil $\mathrm{A}$ and soil B, respectively.

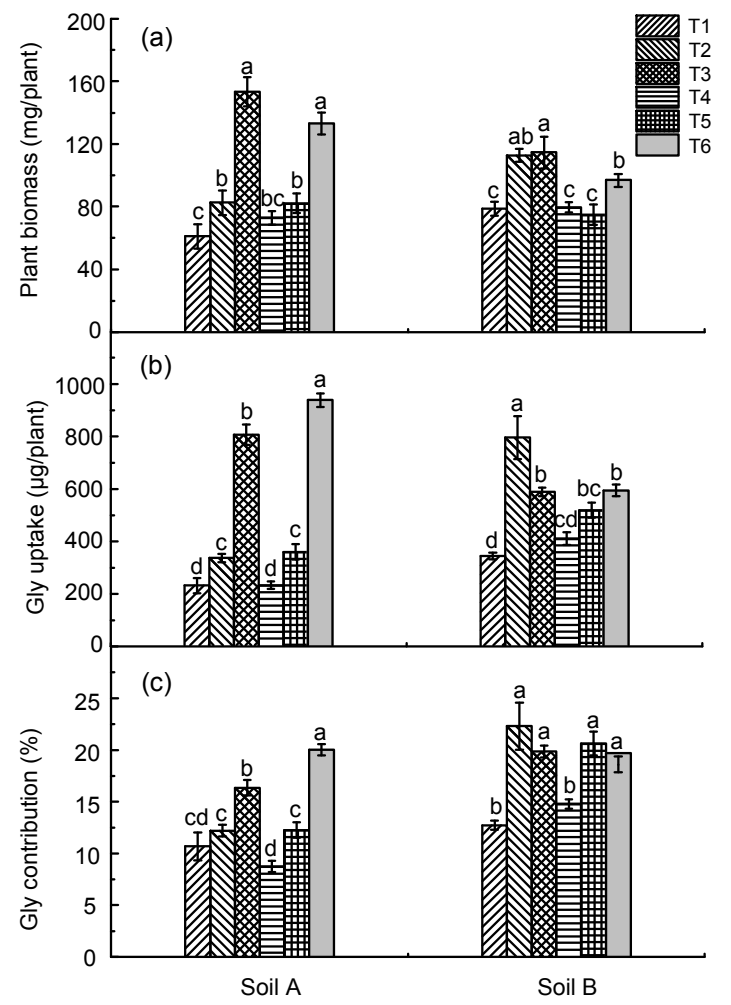

Fig. 2 Rice biomass (a), glycine (Gly) uptake (b), and Gly contribution (c) in the different treatments Different treatments: adsorbed Gly: $\mathrm{NH}_{4}^{+}$weight content is 1:2 (T1), 1:1 (T2), 1:0.5 (T3) at Gly HAS concentration; adsorbed Gly: $\mathrm{NH}_{4}^{+}$weight content is 1:2 (T4), 1:1 (T5), 1:0.5 (T6) at Gly AS concentration. Values are expressed as mean \pm SE of three replications. Points with the same letter are not significantly different $(P>0.05)$

Three-way ANOVA indicated significant effects of the glycine: $\mathrm{NH}_{4}{ }^{+}$ratio, and the interactions of soil type $\times$ glycine: $\mathrm{NH}_{4}{ }^{+}$ratio and glycine concentration $\times$ glycine: $\mathrm{NH}_{4}{ }^{+}$ratio on rice biomass $(P<0.05$; Table 2$)$. However, the main effects of soil type and glycine concentration on rice biomass were not significant.
Table 2 Three-way ANOVA for the effects of soil type, adsorbed glycine (Gly) concentration, adsorbed Gly: $\mathrm{NH}_{4}{ }^{+}$ ratio, and their interactions on rice biomass, Gly uptake, and Gly nutritional contribution after 21-d sterile cultivation

\begin{tabular}{|c|c|c|c|c|}
\hline Source & $d f$ & MS & $F$ & $P$ \\
\hline \multicolumn{5}{|l|}{ Rice biomass } \\
\hline Soil type & 1 & 0.0004 & 3.036 & 0.090 \\
\hline Gly concentration & 1 & 0.0016 & 11.078 & 0.206 \\
\hline Gly: $\mathrm{NH}_{4}^{+}$ratio & 2 & 0.0110 & 76.108 & $<0.001$ \\
\hline Soil type $\times$ Gly concentration & 1 & 0.0005 & 3.650 & 0.064 \\
\hline Soil type $\times$ Gly: $\mathrm{NH}_{4}{ }^{+}$ratio & 2 & 0.0032 & 22.100 & $<0.001$ \\
\hline $\begin{array}{l}\text { Gly concentration } \times \mathrm{Gly}: \mathrm{NH}_{4}^{+} \\
\text {ratio }\end{array}$ & 2 & 0.0007 & 4.551 & 0.017 \\
\hline $\begin{array}{c}\text { Soil type } \times \text { Gly concentration } \times \\
\text { Gly: } \mathrm{NH}_{4}^{+} \text {ratio }\end{array}$ & 2 & 0.0004 & 2.999 & 0.065 \\
\hline \multicolumn{5}{|l|}{ Gly uptake } \\
\hline Soil type & 1 & 41290 & 21.751 & 0.039 \\
\hline Gly concentration & 1 & 862 & 0.454 & 0.505 \\
\hline Gly: $\mathrm{NH}_{4}{ }^{+}$ratio & 2 & 753679 & 397.034 & $<0.001$ \\
\hline Soil type $\times$ Gly concentration & 1 & 44958 & 23.683 & 0.080 \\
\hline Soil type $\times \mathrm{Gly}: \mathrm{NH}_{4}{ }^{+}$ratio & 2 & 382856 & 201.686 & $<0.001$ \\
\hline $\begin{array}{l}\text { Gly concentration } \times \text { Gly: } \mathrm{NH}_{4}^{+} \\
\text {ratio }\end{array}$ & 2 & 44633 & 23.513 & 0.080 \\
\hline $\begin{array}{c}\text { Soil type } \times \text { Gly concentration } \times \\
\text { Gly: } \mathrm{NH}_{4}^{+} \text {ratio }\end{array}$ & 2 & 34505 & 18.177 & 0.002 \\
\hline \multicolumn{5}{|l|}{ Gly nutritional contribution } \\
\hline Soil type & 1 & 305.5 & 157.685 & $<0.001$ \\
\hline Gly concentration & 1 & 1.2 & 0.638 & 0.400 \\
\hline Gly: $\mathrm{NH}_{4}{ }^{+}$ratio & 2 & 226.6 & 116.962 & $<0.001$ \\
\hline Soil type $\times$ Gly concentration & 1 & 0.8 & 0.400 & 0.500 \\
\hline Soil type $\times \mathrm{Gly}: \mathrm{NH}_{4}{ }^{+}$ratio & 2 & 62.9 & 32.477 & $<0.001$ \\
\hline $\begin{array}{l}\text { Gly concentration } \times \mathrm{Gly}: \mathrm{NH}_{4}^{+} \\
\text {ratio }\end{array}$ & 2 & 6.8 & 3.525 & 0.100 \\
\hline $\begin{array}{c}\text { Soil type } \times \text { Gly concentration } \times \\
\text { Gly: } \mathrm{NH}_{4}^{+} \text {ratio }\end{array}$ & 2 & 16.8 & 8.674 & 0.001 \\
\hline
\end{tabular}

\subsection{Rice glycine uptake and glycine nutritional contribution}

Glycine uptake and glycine contribution significantly increased with decreasing $\mathrm{NH}_{4}{ }^{+}$content in soil A $(P<0.05$; Figs. $2 \mathrm{~b}$ and $2 \mathrm{c})$. Their values reached a maximum in T6 for soil A, but in T2 for soil B. After 21-d sterile cultivation, the soil adsorbed glycine contribution for rice total $\mathrm{N}$ uptake varied widely from $8.8 \%$ to $22.6 \%$ in the different treatments. Despite the significant difference of glycine adsorption capacity between the HAS and AS treatments, the adsorbed glycine manifested a similar $\mathrm{N}$ nutritional contribution for rice between the treatments with an equal glycine: $\mathrm{NH}_{4}{ }^{+}$concentration ratio in both soils. 
Three-way ANOVA indicated significant effects of soil type, glycine: $\mathrm{NH}_{4}{ }^{+}$ratio, and the interactions of soil type $\times$ glycine: $\mathrm{NH}_{4}{ }^{+}$ratio and soil type $\times$glycine concentration $\times$ glycine: $\mathrm{NH}_{4}{ }^{+}$ratio on rice glycine uptake and glycine nutritional contribution $(P<0.05$; Table 2).

\section{Discussion}

In soil, approximately $40 \%$ of soil total $\mathrm{N}$ is present in the form of polymers such as proteins and peptides (Schulten and Schnitzer, 1997). Once amino acids are released in soil, many factors affect their abundance, such as their synthesis and destruction by biota, adsorption by clay minerals, and reactions with quinines and reducing sugars (Yu et al., 2002). Gonod et al. (2006) reported that the behavior of amino acid adsorption was closely related to soil clay content. The clay content was only slightly higher in soil B than in soil A, and therefore it apparently did not cause a significant difference in the adsorption capacity for glycine between the two soils. However, the soil with high organic matter is usually accompanied by a high cation exchange capacity (van Cleve et al., 1993). Therefore, more amino acids may be adsorbed onto soil A. In addition, under natural conditions soil organo-mineral complexes usually contain great amounts of active adsorption sites. After five successive washes with $0.5 \mathrm{~mol} / \mathrm{L} \mathrm{K}_{2} \mathrm{SO}_{4}$, the contents of extractable amino acids adsorbed to the soil solid phase were extremely low, and under such a condition, most cation exchange sites may be highly activated and highly affinitive to the amino acids (Cao et al., 2013). Balistrieri and Murray (1987) also reported that some ions, such as $\mathrm{SO}_{4}{ }^{2-}, \mathrm{Mg}^{2+}$, and $\mathrm{Ca}^{2+}$, had weak absorption capacity on soil binding sites, so these ions can easily be removed after five successive washes and then be replaced by glycine. Therefore, soil A, which had a larger cation exchange capacity and high organic matter, had an advantage in absorbing more glycine than soil B (Cao et al., 2013).

Though rice is known as an $\mathrm{NH}_{4}{ }^{+}$-tolerant species, the high accumulation of $\mathrm{NH}_{4}{ }^{+}$in soils affects plant growth negatively, leading to such things as stunted root growth, yield depression, chlorosis of leaves, and reduced amino acid absorption (Britto and Kronzucker, 2002; Persson and Näsholm, 2003; Roosta and Schjoerring, 2008; Balkos et al., 2010; Li et al., 2011a). In our study, a significant inhibition of $\mathrm{NH}_{4}^{+}$ on rice growth, in particular with a high $\mathrm{NH}_{4}^{+}$treatment (e.g. T1, T4), was observed in both soils. Previous studies have demonstrated that plants' capture of amino acids was maximal at high concentrations under hydroponic cultivation (Jones et al., 2005b; Sauheitl et al., 2009). However, results from the three-way ANOVA demonstrated that rice glycine uptake and its nutritional contribution were not related to its sorption capacity but closely related to their glycine: $\mathrm{NH}_{4}{ }^{+}$concentration ratio (Table 2). Glycine uptake was not increased with increasing adsorbed glycine concentration under the condition of high $\mathrm{NH}_{4}{ }^{+}$application rate. At least two alternative explanations can be presented in order to explain this. Amino acid uptake has been proved to be affected by exogenous $\mathrm{C}$ level rather than by the $\mathrm{N}$ level (Persson and Näsholm, 2003). So increasing the content of endogenous $\mathrm{NH}_{4}{ }^{+}$may lead to a major energy cost for $\mathrm{NH}_{4}^{+}$-efflux (Britto et al., 2001). Therefore, the decrease of plant amino acid uptake may be attributed to the insufficient energy supply in the mixed $\mathrm{N}$ source due to the competitive uptake. This agrees with the others' observations, which related the effect to competition for carbon skeleton between root growth and $\mathrm{NH}_{4}{ }^{+}$assimilation in $\mathrm{NH}_{4}{ }^{+}$-fed plants (Roosta and Schjoerring, 2008; Farrell et al., 2014). In addition, $\mathrm{NH}_{4}^{+}$working as a signal down-regulating transcription of the gene encoding the transporter, can also explain its damping effect on amino acid uptake. Notably, the glycine contribution in soil B was slightly more than that in soil A, but its values were not decreased with the increase of $\mathrm{NH}_{4}^{+}$content. It seems that the inhibition effect of $\mathrm{NH}_{4}{ }^{+}$is lower in the soil with low glycine adsorption capacity compared with that with high glycine adsorption capacity, especially in the treatments of glycine half-adsorption saturation.

Rothstein (2010) suggested that the adsorption of amino acids provides little competition for plant and microbial uptake in sandy forest soils. Under the condition of high $\mathrm{NH}_{4}^{+}$application rate, as high as $22 \%$ of rice total $\mathrm{N}$ uptake was derived from soil adsorbed glycine, which indicates that adsorbed glycine theoretically can serve as an important $\mathrm{N}$ source for plant growth with high $\mathrm{NH}_{4}^{+}$application rate. Despite the significant difference of glycine adsorption capacity in both soils, the similar nutritional 
contribution suggested that the high bioavailability presented herein may be more broadly universal. If the relatively short experimental period is considered, amino acid bioavailability may however be significant in the long run. Amino acids are excellent $\mathrm{C}$ and $\mathrm{N}$ sources for both plant root and soil microbes. Therefore, further studies are warranted, which will investigate the extent to which this bioavailability is realized in the field using the ${ }^{13} \mathrm{C},{ }^{15} \mathrm{~N}$ double labeling technology, especially under $\mathrm{NH}_{4}{ }^{+}$redundancy.

\section{Conclusions}

Our results showed that the sorption capacity of glycine was closely related to soils' physical and chemical properties (e.g. organic matter content and cation exchange capacity). After 21-d sterile cultivation, rice biomass was significantly inhibited by a high $\mathrm{NH}_{4}^{+}$application rate. Rice glycine uptake and its nutritional contribution were independent from its glycine sorption capacity, but significantly related to soil type and glycine: $\mathrm{NH}_{4}{ }^{+}$concentration ratio. In spite of the high $\mathrm{NH}_{4}{ }^{+}$application rate, rice uptake of adsorbed glycine accounted for $8.8 \%-22.6 \%$ of rice total $\mathrm{N}$ uptake, which indicates that soil adsorbed glycine theoretically can serve as an important $\mathrm{N}$ source for plant growth.

\section{Acknowledgements}

We thank Xiao-ning DU from Shanghai Research Institute of Chemical Industry in China for skilled ${ }^{15} \mathrm{~N}$ technical assistance.

\section{Compliance with ethics guidelines}

Xiao-chuang CAO, Qing-xu MA, Liang-huan WU, Lianfeng ZHU, and Qian-yu JIN declare that they have no conflict of interest.

This article does not contain any studies with human or animal subjects performed by any of the authors.

\section{References}

Balistrieri, L.S., Murray, J.W., 1987. The influence of the major ions of seawater on the adsorption of simple organic acids by goethite. Geochim. Cosmochim. Acta, 51(5):1151-1160. http://dx.doi.org/10.1016/0016-7037(87)90208-0

Balkos, K.D., Britto, D.T., Kronzucker, H.J., 2010. Optimization of ammonium acquisition and metabolism by potassium in rice (Oryza sativa L. cv. IR-72). Plant Cell Environ., 33(1):23-34.

http://dx.doi.org/10.1111/j.1365-3040.2009.02046.x
Barth, C., Gouzd, Z.A., Steele, H.P., et al., 2010. A mutation in GDP-mannose pyrophosphorylase causes conditional hypersensitivity to ammonium, resulting in Arabidopsis root growth inhibition, altered ammonium metabolism, and hormone homeostasis. J. Exp. Bot., 61(2):379-394. http://dx.doi.org/10.1093/jxb/erp310

Bijlsma, R.J., Lambers, H., Kooijman, S.A.L.M., 2000. A dynamic whole-plant model of integrated metabolism of nitrogen and carbon. 1. Comparative ecological implications of ammonium-nitrate interactions. Plant Soil, 220(1): 49-69. http://dx.doi.org/10.1023/A:1004779019486

Britto, D.T., Kronzucker, H.J., 2002. $\mathrm{NH}_{4}{ }^{+}$toxicity in higher plants: a critical review. J. Plant Physiol., 159(6):567-584. http://dx.doi.org/10.1078/0176-1617-0774

Britto, D.T., Siddiqi, M.Y., Glass, A.D.M., et al., 2001. Futile transmembrane $\mathrm{NH}_{4}^{+}$cycling: a cellular hypothesis to explain ammonium toxicity in plants. PNAS, 98(7):4255-4258. http://dx.doi.org/10.1073/pnas.061034698

Cao, X.C., Chen, X.Y., Li, X.Y., et al., 2013. Rice uptake of soil adsorbed amino acids under sterilized environment. Soil Biol. Biochem., 62:13-21. http://dx.doi.org/10.1016/j.soilbio.2013.02.018

Chen, X.Y., Wu, L.H., Cao, X.C., et al., 2013. An experimental method to quantify extractable amino acids in soils from southeast China. J. Integr. Agric., 12(4):732-736. http://dx.doi.org/10.1016/S2095-3119(13)60291-9

Christou, M., Avramides, E.J., Jones, D.L., 2006. Dissolved organic nitrogen dynamics in a Mediterranean vineyard soil. Soil Biol. Biochem., 38(8):2265-2277. http://dx.doi.org/10.1016/j.soilbio.2006.01.025

Dashman, T., Stotzky, G., 1984. Adsorption and binding of peptides on homoionic montmorillonite and kaolinite. Soil. Biol. Biochem., 16(1):51-55. http://dx.doi.org/10.1016/0038-0717(84)90125-1

Farrell, M., Prendergast-Miller, M., Jones, D.L., et al., 2014. Soil microbial organic nitrogen uptake is regulated by carbon availability. Soil Biol. Biochem., 77:261-267. http://dx.doi.org/10.1016/j.soilbio.2014.07.003

Geisseler, D., Horwath, W.R., 2014. Investigating amino acid utilization by soil microorganisms using compound specific stable isotope analysis. Soil Biol. Biochem., 74:100-105. http://dx.doi.org/10.1016/j.soilbio.2014.02.024

Gonod, L.V., Jones, D.L., Chenu, C., 2006. Sorption regulates the fate of the amino acids lysine and leucine in soil aggregates. Eur. J. Soil Sci., 57(3):320-329. http://dx.doi.org/10.1111/j.1365-2389.2005.00744.x

Guo, J.H., Liu, X.J., Zhang, Y., et al., 2010. Significant acidification in major Chinese croplands. Science, 327(5968): 1008-1010. http://dx.doi.org/10.1126/science.1182570

Henry, H.A.L., Jefferies, R.L., 2003. Plant amino acid uptake, soluble $\mathrm{N}$ turnover and microbial $\mathrm{N}$ capture in soils of a grazed Arctic salt marsh. J. Ecol., 91(4):627-636. http://dx.doi.org/10.1046/j.1365-2745.2003.00791.x

Jones, D.L., Owen, A.G., Farrar, J.F., 2002. Simple method to enable the high resolution determination of total free 
amino acids in soil solutions and soil extracts. Soil Biol. Biochem., 34(12):1893-1902.

http://dx.doi.org/10.1016/S0038-0717(02)00203-1

Jones, D.L., Healey, J.R., Willett, V.B., et al., 2005a. Dissolved organic nitrogen uptake by plants - an important $\mathrm{N}$ uptake pathway? Soil Biol. Biochem., 37(3):413-423. http://dx.doi.org/10.1016/j.soilbio.2004.08.008

Jones, D.L., Shannon, D., Junvee-Fortune, T., et al., $2005 \mathrm{~b}$. Plant capture of free amino acids is maximized under high soil amino acid concentrations. Soil Biol. Biochem., 37(1) 179-181. http://dx.doi.org/10.1016/j.soilbio.2004.07.021

Jones, D.L., Clode, P.L., Kilburn, M.R., et al., 2013. Competition between plant and bacterial cells at the microscale regulates the dynamics of nitrogen acquisition in wheat (Triticum aestivum). New Phytol., 200(3):796-807. http://dx.doi.org/10.1111/nph.12405

Kempinski, C.F., Haffar, R., Barth, C., 2011. Toward the mechanism of $\mathrm{NH}_{4}^{+}$sensitivity mediated by Arabidopsis GDP-mannose pyrophosphorylase. Plant Cell Environ., 34(5):847-858. http://dx.doi.org/10.1111/j.1365-3040.2011.02290.x

Li, B.H., Shi, W.M., Su, Y.H., 2011a. The differing responses of two Arabidopsis ecotypes to ammonium are modulated by the photoperiod regime. Acta Physiol. Plant., 33(2): 325-334. http://dx.doi.org/10.1007/s11738-010-0551-5

Li, B.H., Li, Q., Su, Y.H., et al., 2011b. Shoot-supplied ammonium targets the root auxin influx carrier AUX1 and inhibits lateral root emergence in Arabidopsis. Plant Cell Environ., 34(6):933-946. http://dx.doi.org/10.1111/j.1365-3040.2011.02295.x

Li, Q., Li, B.H., Kronzucker, H.J., et al., 2010. Root growth inhibition by $\mathrm{NH}_{4}^{+}$in Arabidopsis is mediated by the root tip and is linked to $\mathrm{NH}_{4}^{+}$efflux and GMPase activity. Plant Cell Environ., 33(9):1529-1542. http://dx.doi.org/10.1111/j.1365-3040.2010.02162.x

Liu, X.J., Zhang, Y., Han, W.X., et al., 2013. Enhanced nitrogen deposition over China. Nature, 494:459-462. http://dx.doi.org/10.1038/nature11917

Månsson, K.F., Olsson, M.O., Falkengren-Grerup, U., et al., 2014. Soil moisture variations affect short-term plantmicrobial competition for ammonium, glycine, and glutamate. Ecol. Evol., 4(7):1061-1072. http://dx.doi.org/10.1002/ece3.1004

Näsholm, T., Huss-Danell, K., Högberg, P., 2001. Uptake of glycine by field grown wheat. New Phytol., 150(1):59-63. http://dx.doi.org/10.1046/j.1469-8137.2001.00072.x

Näsholm, T., Kielland, K., Ganeteg, U., 2009. Uptake of organic nitrogen by plants. New Phytol., 182(1):31-48. http://dx.doi.org/10.1111/j.1469-8137.2008.02751.x

Persson, J., Näsholm, T., 2001. Amino acid uptake: a widespread ability among boreal forest plants. Ecol. Lett., 4(5): 434-438.

http://dx.doi.org/10.1046/j.1461-0248.2001.00260.x

Persson, J., Näsholm, T., 2003. Regulation of amino acid uptake by carbon and nitrogen in Pinus sylvestris. Planta, 217(2):309-315.

http://dx.doi.org/10.1007/s00425-003-0991-x

Qin, C., Qian, W., Wang, W., et al., 2008. GDP-mannose pyrophosphorylase is a genetic determinant of ammonium sensitivity in Arabidopsis thaliana. PNAS, 105(47): 18308-18313.

http://dx.doi.org/10.1073/pnas.0806168105

Qualls, R.G., Richardson, C.J., 2003. Factors controlling concentration, export, and decomposition of dissolved organic nutrients in the Everglades of Florida. Biogeochemistry, 62(2):197-229. http://dx.doi.org/10.1023/A:1021150503664

Raab, T.K., Lipson, D.A., Monson, R.K., 1999. Soil amino acid utilization among species of the Cyperaceae: plant and soil processes. Ecology, 80(7):2408-2419. http://dx.doi.org/ 10.1890/0012-9658(1999)080[2408:SAAUAS]2.0.CO;2

Roosta, H.R., Schjoerring, J.K., 2008. Root carbon enrichment alleviates ammonium toxicity in cucumber plants. $J$. Plant Nutr., 31(5):941-958. http://dx.doi.org/10.1080/01904160802043270

Rothstein, D.E., 2009. Soil amino-acid availability across a temperate-forest fertility gradient. Biogeochemistry, 92(3): 201-215. http://dx.doi.org/10.1007/s10533-009-9284-1

Rothstein, D.E., 2010. Effects of amino-acid chemistry and soil properties on the behavior of free amino acids in acidic forest soils. Soil Biol. Biochem., 42(10):1743-1750. http://dx.doi.org/10.1016/j.soilbio.2010.06.011

Sauheitl, L., Glaser, B., Weigelt, A., 2009. Uptake of intact amino acids by plants depends on soil amino acid concentrations. Environ. Exp. Bot., 66(2):145-152. http://dx.doi.org/10.1016/j.envexpbot.2009.03.009

Schulten, H.R., Schnitzer, M., 1997. The chemistry of soil organic nitrogen: a review. Biol. Fert. Soils, 26(1):1-15. http://dx.doi.org/10.1007/s003740050335

Stevenson, F.J., 1994. Humus Chemistry: Genesis, Composition, Reactions, 2nd Ed. Wiley, New York, USA, p.87-115.

van Cleve, K., Dyrness, C.T., Marion, G.M., et al., 1993. Control of soil development on the Tanana River floodplain, interior Alaska. Can. J. Forest Res., 23(5):941-955. http://dx.doi.org/10.1139/x93-122

Vinall, K., Schmidt, S., Brackin, R., et al., 2012. Amino acids are a nitrogen source for sugarcane. Funct. Plant Biol., 39(6):503-511. http://dx.doi.org/10.1071/FP12042

Wang, X.L., Ye, J., Perez, P.G., et al., 2013. The impact of organic farming on the soluble organic nitrogen pool in horticultural soil under open field and greenhouse conditions: a case study. Soil Sci. Plant Nutr., 59(2):237-248. http://dx.doi.org/10.1080/00380768.2013.770722

Wang, X.L., Tang, D.M., Huang, D.F., 2014. Proteomic analysis of pakchoi leaves and roots under glycine-nitrogen conditions. Plant Physiol. Biochem., 75:96-104. http://dx.doi.org/10.1016/j.plaphy.2013.12.012 
Warren, C.R., 2006. Potential organic and inorganic N uptake by six Eucalyptus species. Funct. Plant Biol., 33(7):653-660. http://dx.doi.org/10.1071/FP06045

Warren, C.R., Adams, M.A., 2002. Possible causes of slow growth of nitrate-supplied Pinus pinaster. Can. J. Forest Res., 32(4):569-580. http://dx.doi.org/10.1139/x01-225

Warren, C.R., Adams, P.R., 2007. Uptake of nitrate, ammonium and glycine by plants of Tasmanian wet eucalypt forests. Tree Physiol., 27(3):413-419. http://dx.doi.org/10.1093/treephys/27.3.413

Yu, Z., Zhang, Q., Kraus, T.E.C., et al., 2002. Contribution of amino compounds to dissolved organic nitrogen in forest soils. Biogeochemistry, 61(2):173-198. http://dx.doi.org/10.1023/A:1020221528515

\section{中文概要}

\section{题 目: 铵态氮施用量对水稻幼苗吸收土壤吸附态氨基酸 的影响}

目 的: 通过采用无菌土培培养方法, 阐明外源高铵态氮 施用量与水稻幼苗生长、土壤吸附态氨基酸吸收 之间的关系。
创新点: 借助无菌培养和 ${ }^{15} \mathrm{~N}$ 同位素示踪方法, 揭示高铵 态氮浓度条件下土壤吸附态氨基酸对水稻幼苗 生长发育及其氮营养贡献的影响。

方 法: 采集两种不同生态系统的土壤 $\mathrm{A}$ 和 $\mathrm{B}$, 经 $0.5 \mathrm{~mol} / \mathrm{L}$ $\mathrm{K}_{2} \mathrm{SO}_{4}$ 连续淋洗 5 次, $121{ }^{\circ} \mathrm{C}$ 灭菌 $30 \mathrm{~min},{ }^{15} \mathrm{~N}$ 甘氨酸处理后, 根据甘氨酸吸附曲线（图 1) 确 定甘氨酸吸附饱和点和吸附半饱和点, 然后向土 壤中添加一些不同浓度的铵态氮, 水稻幼苗无菌 培养 21 天后, 用 MAT-271 质谱仪测定水稻幼苗 氨基酸吸收量。

结 论: 实验结果表明土壤甘氨酸吸附能力大小与土壤理 化性质紧密相关, 如有机质和阳离子交换量。外 源高铵态氮水平显著抑制水稻幼苗生长发育 $(P<0.05)$, 但甘氨酸吸收及其氮营养贡献与甘氨 酸吸附能力大小无关, 而与土壤吸附态甘氨酸和 铵态氮的浓度比值显著相关 $(P<0.05)$ 。经过 21 天的无菌培养, 土壤吸附态氨基酸对水稻的氮营 养贡献率达 $8.8 \%$ 22.6\%, 表明土壤吸附态氨基 酸理论上可能作为植物的一种潜在重要营养氮 源。

关键词: 吸附态氨基酸; 铵态氮; 甘氨酸生物有效性; 无 菌培养 